\title{
Morar Anunciado: \\ a veiculação publicitária \\ da Unilabor na \\ mídia paulistana
}

\author{
Osvaldo Bruno Meca Santos da Silva, \\ Fernando Atique*
}

\begin{abstract}
Resumo A fábrica de móveis Unilabor funcionou na cidade de São Paulo de 1954 a 1967, na Vila Brasílio Machado, e foi um ícone da relação entre a atividade comunitária religiosa, a partir da humanização do trabalho e a partilha de gestão da empresa, com a Arte Moderna e o design de mobiliário. Nessa relação atípica, a Unilabor utilizou diferentes estratégias e materiais visuais em sua publicidade, que, além do objetivo principal dos anúncios que era a venda de móveis, também comunicava aos potenciais consumidores ideias de gosto, voltadas a um projeto de modernidade para o espaço doméstico.
\end{abstract}

Palavras-chave: publicidade, mobiliário, domesticidade.

\section{El vivir anunciado: la divulgación publicitaria de Unilabor en los medios sociales de la ciudad São Paulo}

Resumen La fábrica de muebles Unilabor funcionó en la ciudad de São Paulo desde 1954 hasta 1967, en la Vila Brasílio Machado, y fue un icono de la relación entre la actividad comunitária religiosa, desde la humanización del trabajo y la división de la gestión de la empresa, con el Arte Moderno y el diseño de mobiliário. En esa relación atípica, Unilabor utilizó diferentes estrategias y materiales visuales en su publicidad que, además del objetivo principal de los anúncios, que era la venta de muebles, también comunicaba a los pontenciales consumidores ideas de gusto, dirigidas a un proyecto de modernidade para el espacio doméstico.

Palabras clave: publicidad, mobiliario, domesticidad.

\section{The Home Under Advertisement: Unila- bor's advertising in the city of São Paulo media}

\begin{abstract}
The Unilabor furniture factory operated in the city of São Paulo, from 1954 to 1967, in Vila Brasílio Machado, and it was an icon of the relationship between religious community activity, based on the humanization of work and the sharing experience in the company management, with Modern Art and furniture design. In this atypical relationship, Unilabor used different strategies and visual materials in its advertising, which, in addition to the main objective of the ads (which was the furniture sale), also communicated to potential consumers some ideas of taste, related to a project of modernity for the domestic space.
\end{abstract}

Keywords: advertising, furniture, domesticity. 


\section{Experimentações Produtivas, Engrenagens Sociais}

A fábrica de móveis Unilabor foi uma experiência da relação entre a atividade comunitária religiosa com a Arte Moderna. Fundada pelo frei dominicano João Baptista Pereira dos Santos (1913-1985), pelo ferramenteiro Antônio Thereza (1923 -2001), e pelo artista plástico Geraldo de Barros (1923-1998), funcionou de 1954 a 1967, na zona sul da cidade de São Paulo, na Vila Brasílio Machado, próxima ao bairro operário do Ipiranga.

Em quase todo o período de sua existência, pois no início experimentou a produção de liquidificadores e de outros artefatos sob encomenda, fabricou e comercializou móveis modernos projetados por Geraldo de Barros, com o auxílio de operários capacitados em serralheria e marcenaria.

A fábrica foi precursora na ideia de elaborar móveis modernos, modulares e seriados, adaptáveis aos novos padrões de moradia dos segmentos médios da população, ou seja, em pequenos espaços, sobretudo apartamentos, mas preocupada em não perder a funcionalidade e a beleza consideradas típicas da modernidade (CLARO, 2004, p.35).

Outra peculiaridade da fábrica é que o projeto do frei João Baptista almejava empregar os princípios do movimento europeu Economia e Humanismo', que propunha uma tentativa de terceira via entre o capitalismo e o comunismo, a partir da humanização do trabalho e do trabalhador (ANGELO, 2010, p. 59; BOSI, 2012, p. 25; PONTUAL, 2016, p.18).

Este projeto foi instalado na Unilabor com o nome de comunitarismo ${ }^{2}$, uma vez que frei João Baptista construiu uma comunidade de trabalho em que os operários eram associados, ou seja: tinham direito de tomada de decisão na gestão da fábrica. Além disso, a fábrica funcionava como um centro de produção cultural para os operários e seus familiares (com biblioteca, escola, atividades artísticas etc.), nomeado como Centro Social Cristo Operário (CLARO, 2004, 55).

Esse preâmbulo é importante para a compreensão de que a Unilabor foi criada e

* Osvaldo Bruno Meca Santos da Silva é Historiador, Mestre pelo Programa de Pós Graduação em História pela Escola de Filosofia, Letras e Ciências Humanas da Universidade Federal de São Paulo, ORCID <https://orcid. org/0000-0002-3252-4269>. Fernando Atique é Arquiteto e Urbanista, Professor Departamento de História da Universidade Federal de São Paulo vínculo em, ORCID <https://orcid. org/0000-0002-7681-1227>. desenvolvida a partir de um conjunto atípico de relações: uma ordem da igreja católica fundada no século XIII, artistas plásticos do movimento moderno, trabalhadores especializados em serralheria e marcenaria. A partir dessa rede de associações, nos perguntamos: como essa fábrica comercializava seus móveis? De quais instrumentos de comércio a Unilabor lançou mão para divulgar seus produtos no mercado? Como o ideal de morar era representado a partir da publicidade da fábrica?

O período de existência da Unilabor coincide com a Guerra Fria e com as propostas de gestão política bipolarizada entre os sistemas econômicos capitalista e socialista. Esta cisão, embora não descarte a dimensão cotidiana com a produção de bens materiais, como móveis, era vista, no Brasil, como um embate prejudicial. A Unilabor, assim 
10 Movimento Economia e Humanismo foi fundado na França, pelo frei Louis-Joseph Lebret, também conhecido por Padre Lebret, na década de 1940. Com as bases a partir da filosofia tomista, própria dos estudos da Ordem dos Pregadores, mas também uma leitura a partir de Karl Marx, somada a uma vivência de trabalhadores e a França durante e pós II Guerra Mundial, esse movimento tinha como objetivo congregar um conjunto de pessoas de diversas vertentes de formação para repensar modelos econômicos e sociais da Europa e até de outros continentes, como a América do Sul, para propor uma economia humana a partir de outros modelos de trabalho, de urbanismo, de economia.

2Esse foi o termo cunhado pelo frei João Baptista Pereira dos Santos em seu livro Uma revolução na estrutura da empresa. É uma derivação de Comunidade de Trabalho, que segundo o próprio frei revelaria o regime de empresa e trabalho que era adotado na Unilabor, como a participação dos empregados nas decisões da fábrica e o direito à propriedade da empresa em uma sociedade de cotas a partir do tempo de trabaIho. Como a legislação trabalhista brasileira não abrangia esse modelo de empresa, a Unilabor teve que ser registrada como uma cooperativa de trabalho.

3 Domesticidade é um termo ainda do século XIX, mas que como disciplina de diversas áreas do conhecimento ainda se desenvolve como campo de estudo. A domesticidade, nesse sentido, é uma fonte de pesquisa, em que as formas de habitar e seus desdobramentos (maneiras de convivência, recortes de classes e gêneros, análises acerca do conforto e materiais, e a divulgação desses modelos de experiência de habitação), formam o escopo para a compreensão de sociedades, hierarquias e culturas. como algumas outras iniciativas, procurou ser uma terceira via, esquivando-se tanto do jogo capitalista quanto do que genericamente era denominado de comunista. A Unilabor procurou, na linguagem de seu fundador, afastar-se dos dois chifres do diabo, abrindo uma nova via de relações.

A escolha em estudar a fábrica de móveis Unilabor e sua produção publicitária se deve à percepção de que é inegável a participação dos móveis na vida cotidiana. As tarefas mais básicas, como dormir e se alimentar, até as que exigem outros esforços, como estudar e trabalhar, na maioria das vezes, são feitas com o auxílio de um móvel. Além disso, as utilidades dos móveis extrapolam o uso do corpo, e também servem para guardar objetos e utensílios, apoiar equipamentos, materiais, fotografias. E, por fim, o móvel cumpre a função de elemento de decoração no espaço doméstico, ou seja, cumpre o papel de formar ambientes de representação que estruturam a vida doméstica.

A discussão acerca da domesticidade ${ }^{3}$ - expressão que na historiografia brasileira assumiu certa dianteira nos últimos anos, sobrepujando expressões como modos de morar - é de total relevância, exatamente porque traz, em si, uma preocupação na confluência dos saberes eruditos, dos ocupantes, dos legisladores e também, como é o caso, das representações midiáticas.

Nesse sentido, o livro Domesticidade, Gênero e Cultura Material, é uma importante referência para esse campo de estudo, com destaque para o artigo da pesquisadora Anahi Ballent, em que ela estuda a revista Claudia da Argentina, mas que podemos tomar emprestado para nossa análise acerca da publicidade da Unilabor, ou seja, um triplo processo de modernização: "da imprensa (formato, impressão, projeto gráfico e conteúdos), das imagens e papéis sociais femininos [...] e das formas de morar dos setores médios - novos tipos de moradia, residência para jovens mudanças em materiais de construção, decoração etc." (BALLENT, 2017, p.293).

Sendo também a modernidade um campo de experiências e experimentações, julgamos que a fábrica de móveis Unilabor e seu projeto moderno de uma terceira via, tenha observado a publicidade por uma lente artística, o que pode ter aplacado as críticas que porventura tenha recebido dos religiosos e dos operários como "ferramenta do mercado" (SANTOS, 1964).

\section{Marcas Gráficas, Demarcações Políticas}

Ainda que a fábrica tenha iniciado sua produção em 1954, observamos a partir das fontes que foi apenas em 1957 que seu primeiro anúncio foi veiculado em uma mídia impressa. Com este marco temporal, de 1957 a 1967, passamos a olhar, detidamente, as revistas de decoração e os jornais do período, como Casa \& Jardim, O Estado de S. Paulo, e, em especial a Folha de S. Paulo. Dessa maneira, foi obtido um universo de 41 anúncios. Essas peças foram tratadas da seguinte maneira: digitalizadas, e analisadas à luz da bibliografia historiográfica, levando em conta alguns fatores, como o veículo em que foram publicadas (elementos da história da leitura que contemplam aspectos de tiragem, composição, tipografia, fotografia e papel); as composições nas páginas; técnicas de advertisement, uma vez que a Unilabor usou tanto charges, quanto fotografias e clichés, mas, também, fórmulas mistas, como desenhos e escrita à mão livre com 
Figura 1: Marca da Unilabor, desenhada por Geraldo de Barros, c. 1957. Fonte: Retirado do livro Design Visual: 50 anos, de Alexandre Wollner. Desenho vetorizado no software Adobe Ilustrator a partir da reprodução. esferográfica; mensagens diretas e subliminares, pois algumas composições permitem verificar discursos sociais sobre a vida moderna, em especial, em apartamentos; e a autoria, para compreender quem foram os autores dos anúncios.

Para compreender a formação da publicidade da Unilabor e os ideais referentes à questão da domesticidade, avaliamos que devemos partir da criação da marca da fábrica e as disputas envolvidas.

Não é possível, a partir das fontes e da bibliografia, determinar a data exata do lançamento da marca da Unilabor (figura 1). O desenho é atribuído por frei João Baptista a Geraldo de Barros, e foi criado, segundo apontamentos de Chico Homem de Melo e Alexandre Wollner, em 1957, e utilizado até o fechamento da fábrica, como atestam os anúncios (MELO, 2014, p. 225; WOLLNER, 2003, p. 120).

Sua formulação contém apenas três elementos: duas mãos e um martelo. Não há texto ou outros símbolos (além da aplicação em preto sobre o fundo verde). Sua interpretação, no entanto, é um pouco mais complexa. Afinal, algumas questões podem ser formuladas a partir disso: as mãos seriam de apenas uma pessoa ou de pessoas diferentes? A depender da resposta, haveria duas interpretações para essa ferramenta. E outra questão: o martelo, símbolo associado à União das Repúblicas Socialistas Soviéticas (URSS) para o período estudado, não deixaria margem para interpretações diversas? Se a exploração do elemento religioso - a cruz - foi usado, por que associá-la ao martelo?

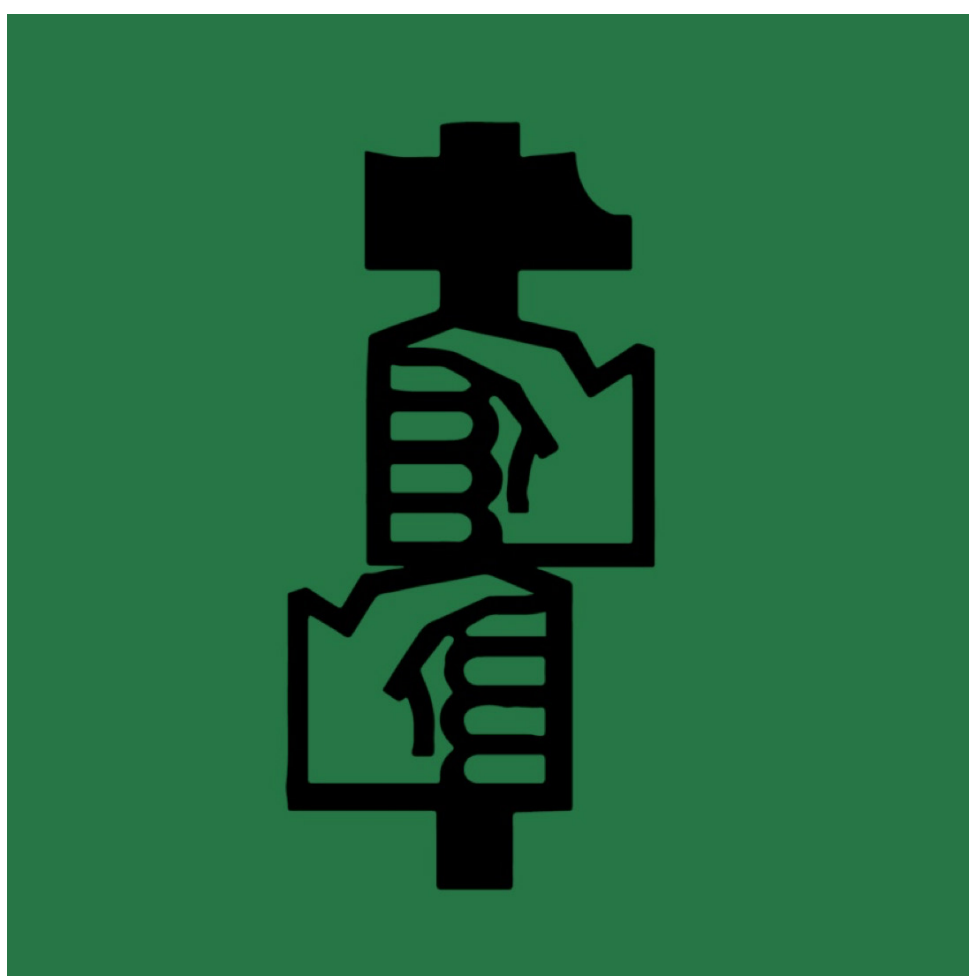


Frei João Baptista descreve, em poucas linhas, o que ele pensa sobre a marca. Ele diz que durante o processo de estabelecimento da Unilabor

[cogitou-se] arrumar um emblema: - é o que figura na capa deste livro [Uma revolução na estrutura da empresa] e em todos os nossos papéis: - sobre fundo verde duas mãos reunidas seguram um martelo que tem forma de cruz. O autor foi naturalmente o Geraldo [de Barros], e mais uma vez a intuição dele encontrou-se com a minha: o verde, côr [sic] da natureza, simboliza a paz e a esperança a cruz só pode ser a de Cristo que une realmente o mundo operário e redime seu trabalho. Que surja uma Unilabor no campo e um dia cruzaremos também o martelo com a foice sem precisar para isto de nenhum fundo vermelho. (SANTOS, 1962, p.49)

Esse texto é importante por conter muitas chaves de análise. Em primeiro lugar, a preocupação com a criação de uma marca (ou emblema) única para a Unilabor, pois a ideia era estar presente em todos os materiais da organização (capas de livros, papéis timbrados, cartões de visita e os próprios anúncios). Frei João Baptista, nos parece, se ocupou de criar uma identidade para a empresa, e isso denota cuidado na questão visual.

Por outro lado, não é algo plenamente praticado. Observamos em toda a documentação, uma disparidade na aplicação dos elementos, fazendo com que o padrão estético não fosse mantido de forma linear. Outro fato é que frei João Baptista talvez não estivesse diretamente ou totalmente dedicado a essas questões, uma vez que as decisões eram tomadas em assembleia. Ou, como defendemos, havia dois tipos de divulgação: uma para dentro dos muros da fábrica e outra para fora.

Uma análise recente acerca da marca da Unilabor é do escritor M. A. Amaral Rezende. Em um livro dedicado ao aprofundamento da obra de Geraldo de Barros, organizado pela filha do artista, Fabiana de Barros, uma das seções é sobre a Unilabor e a marca criada. Segundo M. A. Amaral Rezende

Quando criou a marca da Unilabor, Geraldo de Barros lançou a primeira marca-sonho: uma síntese simbólica capaz de projetar o trabalho novo, aquele realizado pelo trabalhador não alienado, exercendo a propriedade coletiva. A sua proposta visual concentra a unidade dos trabalhadores entre si, capaz de realizar a palavra de ordem comunista, 'Trabalhadores de todo mundo, uni-vos'. [...] Enigmáticos são os duplos punhos, rigorosamente iguais, no cabo do martelo. Por que dois punhos se a regra simbólica é apenas um? E mais, dois punhos, com sentidos diferentes, não poderiam denotar uma disputa? Esta contradição, como aquela da luta de classes, resolve-se no próprio desenho. Na marca, não são punhos de duas pessoas. Pertencem a uma única pessoa porque são idênticos. Ela traz o martelo no peito, como se apertasse uma cruz ou portasse uma bandeira, aquela da utopia da produção como trabalho não alienado, o sonho de Geraldo de Barros. (BARROS, 2013, p. 134)

É possível notar que, segundo o autor, Geraldo de Barros estava envolvido e engajado na questão do trabalho e na representação de um trabalho comunitário, uma vez que seu projeto visual revelava os elementos essenciais acerca desse tema: a mão do trabalhador e sua ferramenta, e, mais que isso, uma mensagem de libertação a partir do trabalho. Ainda que não seja contraditório ao que frei João Baptista pensa sobre 
a marca, na análise de M.A. Amaral Rezende, a questão religiosa é pouco explorada por Geraldo de Barros.

De fato, mesmo contendo três elementos, essa é uma marca polissêmica, em que a recepção pode gerar diversas interpretações, pois há vários intertextos envolvidos (comunismo, catolicismo, trabalho comunitário). Mesmo com tantas possibilidades de interpretação e talvez até mesmo confusões, essa foi a marca utilizada até o fim da Unilabor, em todos seus materiais visuais e de papelaria (papel timbrado, cartão de visita, catálogo etc.) e em alguns anúncios.

No entanto, na marca, há um elemento ausente: o mobiliário. Em nenhum momento, ou mesmo em suas interpretações, há margem para uma identificação com aquilo que a fábrica produzia. Ainda que houvesse uma ferramenta essencial para a fabricação de móveis, o martelo, isto não significava muito, pois poderia fazer referência à produção de outra variedade de itens.

Chico Homem de Melo, em um livro sobre o design nacional na década de 1960, faz uma menção à Unilabor e sua marca. Entre parênteses, ele diz que "o curioso sinal da Unilabor parece ter sido pensado mais como emblema interno - ecoando cartazes e bandeiras da militância política do construtivismo russo - que como sinal destinado ao mercado de consumo de móveis" (MELO, 2014, p. 224).

A história não é feita somente a partir do que foi revelado, usado, manuseado, conhecido. Ao contrário, é possível, e torna muito mais interessante o universo da pesquisa, buscar e analisar o que também foi omitido, desvalorizado, preterido. Para Carlo Ginzburg, os historiadores "cada vez mais se interessam pelo que seus predecessores haviam ocultado, deixado de lado ou simplesmente ignorado" (GINZBURG, 2011, p. 11).

Nesse sentido, observamos que houve outra proposta de marca para a Unilabor, em que seu sentido ficava evidente: a fabricação de móveis modernos. Porém, tanto essa

4Mantemos a grafia original, com a inicial minúscula. A forminform foi fundada em 1958 e manteve suas atividades até 1973 . Em 1986 foi reaberta, por herdeiros da família de Ruben Martins, e funciona até os dias atuais. marca, como sua possível criadora, a agência forminform ${ }^{4}$ não são destacadas pela historiografia.

A forminform foi uma das iniciativas que esteve próxima da Unilabor, e há hipóteses de que participou, pelo menos de um curto período da produção publicitária da fábrica. Segundo Sabo, a forminform foi fundada a partir de uma sociedade entre Geraldo de Barros, Alexandre Wollner (1928-2018) e Ruben Martins (1929-1968) (SABO, 2011, p. 31).

Não é apenas o fato de Geraldo de Barros partilhar o trabalho entre Unilabor e forminform que torna essas experiências comuns. O primeiro escritório da forminform foi instalado no mezanino da loja da Unilabor localizada na Praça da República, 119. Além disso, Ruben Martins, também trabalhou na Unilabor como desenhista e decorador, possivelmente auxiliando nos pedidos dos móveis modulares, até 1958. A bibliografia nos atesta que um dos primeiros trabalhos da forminform foi justamente a (re)criação da marca da Unilabor (figura 2) (SABO, 2011, p. 29; MELO, 2014, p. 225).

Casa de ferreiro, espeto de ferro. A primeira providência da forminform foi cuidar da identidade de sua anfitriã, a Móveis UL. No logotipo, o nome da loja é rompido 
Figura 2: Marca da Unilabor, desenhada pela forminform, $\mathrm{c}$. 1958. Fonte: Retirado do livro "Design Visual: 50 anos", de Alexandre Wollner. Desenho vetorizado no software Adobe Ilustrator a partir da reprodução.

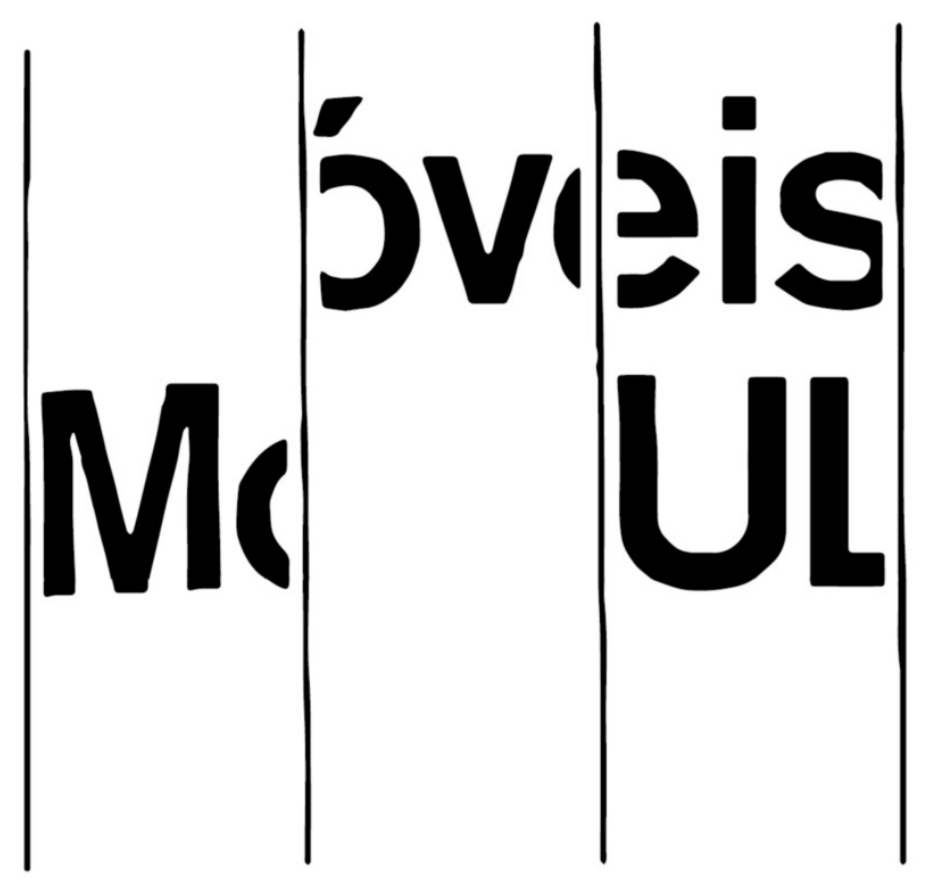

por um diagrama vertical, dentro do qual desliza sem perder a leitura, reforçando a qualidade móvel de seus produtos. O resultado ecoa visualmente o carro-chefe da Unilabor, uma estante composta por finos pórticos de ferro, pelos quais passam pequenos armários e prateleiras modulares de posição variável, que garantem sua estabilidade (MELO, 2014, p. 225).

Portanto, houve a proposta de outra marca para a Unilabor, em que ficava evidente seu produto comercializado (tanto pela questão textual como o próprio desenho, representando uma estante), e produzida por um conjunto de profissionais pioneiros no design brasileiro, criadores de marcas a partir da teoria do bom design, baseado na escola de Ulm.

Perguntamo-nos, então: por qual motivo essa não foi a marca utilizada? Talvez essa tenha sido uma disputa da Unilabor em que frei João Baptista, Geraldo de Barros e todos os trabalhadores tenham participado. Afinal, do que não queriam abrir mão, preservando o logo em que figura o martelo? O que o logo criado pela forminform deixa de revelar sobre a fábrica?

O pesquisador Adrian Forty, defende que a formação de uma marca está menos ligada a questões de formação de gosto ou até mesmo alinhamento a uma linguagem moderna, e mais a uma intenção de "satisfazer objetivos comerciais" (FORTY, 2013, p. 205).

No entanto, a crítica de Adrian Forty não é possível a partir da leitura do projeto de empresa da Unilabor, uma vez que, em suas contradições, alimentava na escolha da marca questões que iam além do objetivo comercial, inclusive em sua publicidade. 
Figura 3: Fotografia do exterior da fábrica Unilabor. Geraldo de Barros, s.d. Fonte: Arquivo da Província Frei Bartolomeu de Las Casas. Caixa Centro Social Cristo Operário.
Parece que dar conta de todo o projeto da Unilabor em uma única marca era uma tarefa difícil, e talvez o que prevaleceu foi o elemento religioso e do trabalho comunitário, em contraposição a uma identidade que representasse o produto final: o móvel moderno (que além disso evidenciava uma característica específica da Unilabor, a modulação).

Por fim, quando analisamos a aplicação da marca em letreiros na fábrica e nas lojas da Unilabor, podemos chegar a hipóteses mais interessantes acerca da divulgação para dentro e para fora dos muros da fábrica.

Uma série de fotos de Geraldo de Barros (e outras de autoria desconhecida) retrataram como a marca era aplicada no ambiente da fábrica, ou seja: é possível inferir que há uma identidade visual própria para o ambiente fabril, pensada para criar um ambiente em que os operários pudessem se identificar com a marca e com o que estava sendo produzido, na linha sugerida por Chico Homem de Melo. Talvez, por isso, a marca que se perpetuou foi a que denotava justamente a questão comunitária.

Em um exemplo de letreiro no interior da fábrica (figura 3), só que da parte externa do galpão, também havia a marca gráfica com as mãos e o martelo, e a parte escrita era acompanhada de um atributo da fábrica, descrita do mesmo jeito que frei João Baptista pregava, ou seja, uma "comunidade de trabalho".

O reforço do sentido de comunidade de trabalho a partir dos elementos visuais foi, segundo as fontes pesquisadas, exclusivo ao espaço da fábrica. Como era então em outros ambientes, como as lojas, e na publicidade? Em alguns casos, apenas a marca gráfica. Em outros, nem isso: apenas o nome por extenso.

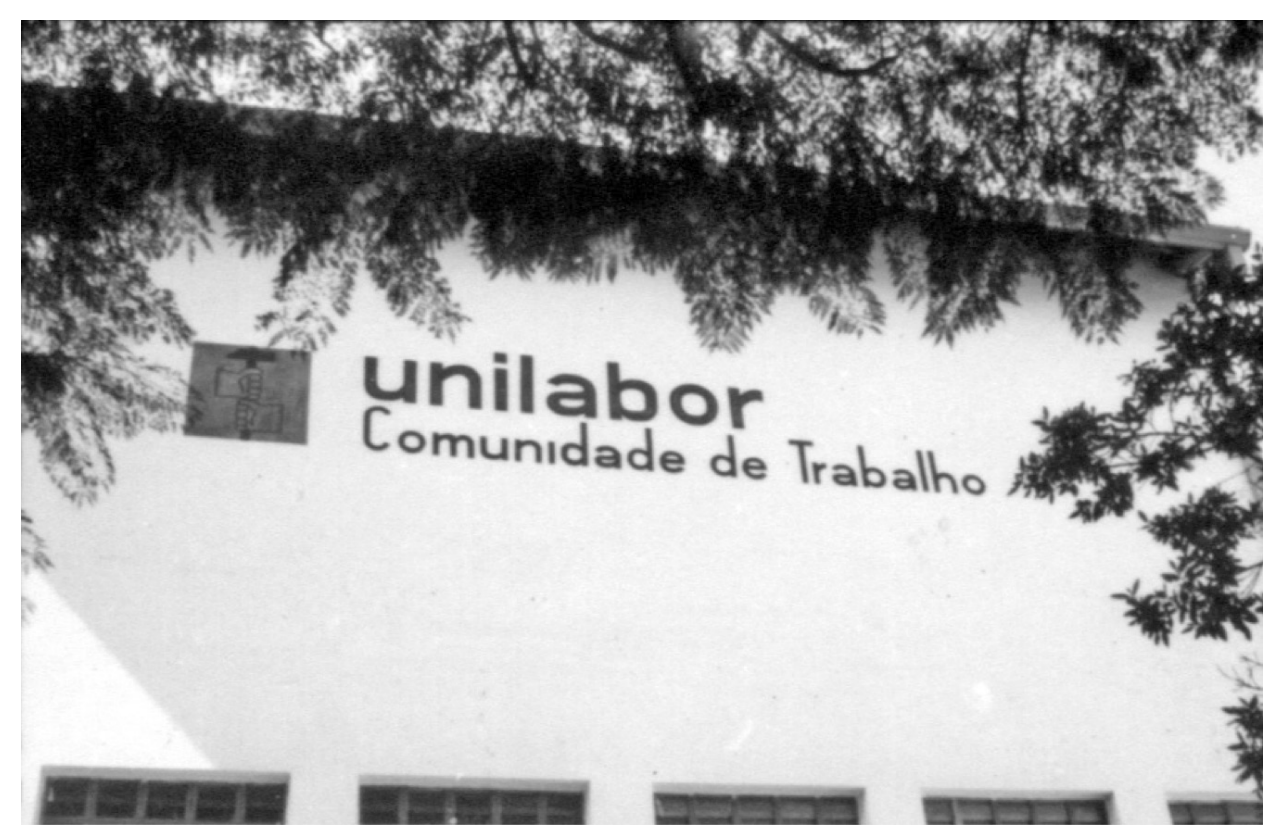


Figura 4: Fotografia do exterior da loja Unilabor. Autoria desconhecida, s.d. Fonte: Arquivo da Província Frei Bartolomeu de Las Casas. Caixa Centro Social Cristo Operário.

Figura 5: Fotografia do exterior da fábrica Unilabor. Autoria desconhecida, s.d. Fonte: Arquivo da Província Frei Bartolomeu de Las Casas. Caixa Centro Social Cristo Operário.
A primeira loja foi inaugurada em 1957, na Praça da República, 119. Sua fachada (figura 4) possuía a inscrição "Unilabor Móveis UL", seguindo a mesma família tipográfica empregada nos anúncios. Havia também uma placa lateral com a inscrição "UL".

Por que havia essa distinção na questão da identidade visual? Era algo deliberado pela assembleia dos operários que a loja não apresentaria o aspecto comunitário da fábrica, que perpassava seu sistema de produção? Apresentar o elemento comunitarista possibilitaria um prejuízo publicitário e mercadológico à marca? Ou, ao contrário, não era justamente essa especificidade de um elemento marcante e inovador que poderia ser explorado?

O caso mais emblemático dessa diferenciação em relação à identidade visual dos espaços físicos da Unilabor está circunscrito à própria fábrica. Em uma fotografia (figura 5) da parte externa da fábrica, a partir da Rua Vergueiro, é possível observar que foi adicionada uma placa com a inscrição "cooperativa de trabalho móveis unilabor exposição aqui", mas, ao fundo, está a permanência da inscrição "unilabor comunidade de trabalho".
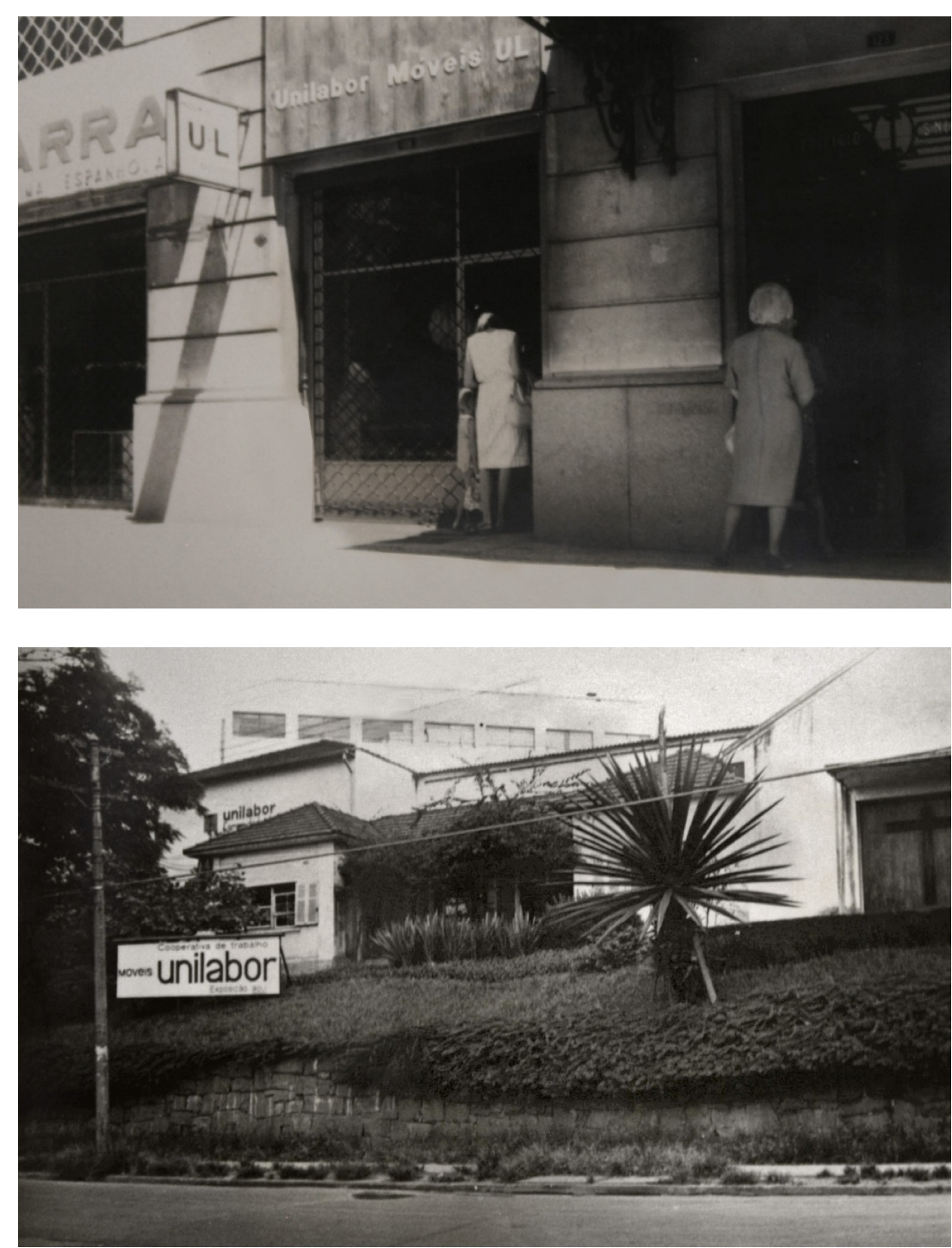
Nos perguntamos, então, por que, para o público, dois termos são utilizados? O que implica utilizar "comunidade" ou "cooperativa" na divulgação da fábrica?

Essa diferença nos faz pensar, como mencionamos acima, que havia uma política de divulgação diferente para dentro dos muros da fábrica e para fora dos muros em sua fase consolidada, posterior a 1957. Afinal, por que uma inscrição interna da fábrica, mais antiga, fazia menção àquele espaço como comunidade, e uma placa posterior voltada para a rua, e exibindo a possibilidade de visitar a exposição dos móveis na fábrica, fazia menção à cooperativa? Por que houve essa mudança de expressão?

A partir da análise das fontes, infere-se que a Unilabor, para ser competitiva no mercado, limitou a questão comunitária entre seus muros, assim como por haver uma questão política envolvida, uma vez que divulgar uma empresa com esse modelo poderia gerar confusões dessa estrutura de trabalho com ideais socialistas, e assim não manteria o caráter de terceira via. Essas hipóteses que explicam parte das inclusões e das omissões nas identidades visuais da publicidade da Unilabor, como também dos seus espaços físicos.

\section{Fusões Repertoriais, Anúncios Testemunhais}

Outra questão importante a analisar diz respeito à questão dos espaços físicos da Unilabor: se havia exposição de móveis, também havia a venda dos mesmos? Se as lojas eram localizadas em endereços de segmentos médios da população (Praça da República, Rua Augusta, Rua Domingos de Morais e Avenida Santo Amaro), havia comercialização deste padrão de mobiliário também em uma área operária? Se em algum período houve a comercialização de móveis na fábrica, a questão do trabalho comunitário tornou-se mais palatável às pessoas responsáveis pela divulgação.

Ainda que a fábrica tenha começado as atividades em 1954, sua consolidação para o comércio varejista nos parece mais tardia. Seu início foi marcado por uma produção a partir de encomendas. Mauro Claro afirma que a primeira encomenda, ainda no ano de 1954, foi um conjunto de peças para o apartamento de Paulo Emílio Sales Gomes (1916-1967).

O próprio Geraldo de Barros decorou sua casa com móveis da Unilabor. Em uma matéria da Revista Casa \& Jardim (figura 6) sobre uma reforma na residência do artista, observase, entre outros elementos, que os móveis da Unilabor fizeram parte da readequação do espaço, pois "os móveis e os motivos decorativos, com focos de luz indireta, traduzem o bom gôsto [sic] de uma família moderna" (CASA \& JARDIM, 1958, p. 16).

Por conta disso, nos parece que o início da Unilabor contou com uma rede de divulgação fora do padrão publicitário, para focar em uma divulgação a partir de uma rede de pessoas. Há uma lacuna na documentação de quais foram as encomendas e como a Unilabor conseguiu se manter durante três anos apenas a partir de um ciclo comum de personagens. Sua primeira loja foi aberta, como já mencionado, em 1957, na Praça da República.

Pelo menos seis meses separam a inauguração da loja inicial da Unilabor do primeiro anúncio que temos notícia. Ele foi publicado em 30 de junho de 1957, no jornal 0 Estado de S. Paulo (figura 7). 


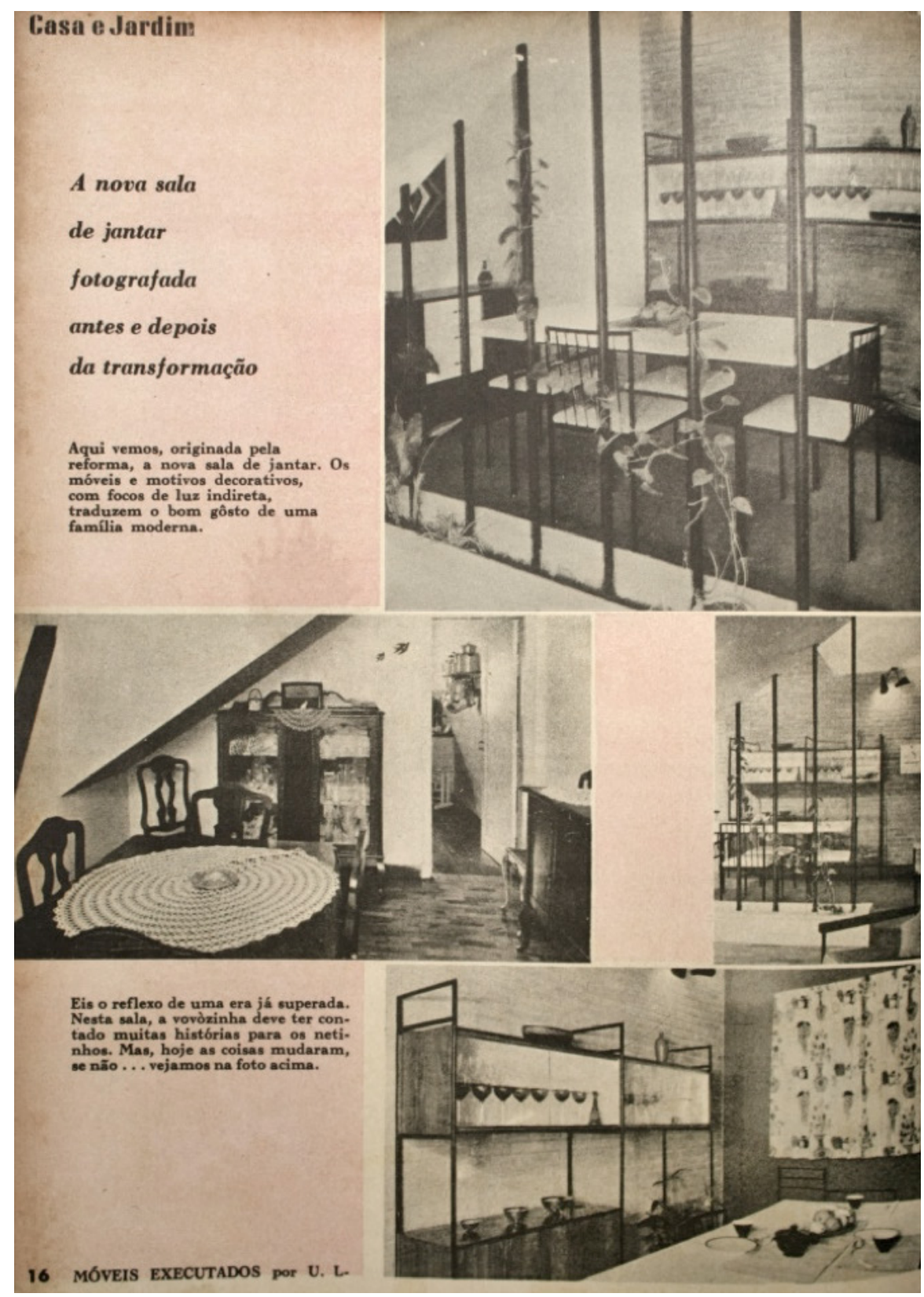

Figura 6 (topo): "Uma reforma feliz". Fonte: Revista Casa \& Jardim. Junho de 1958, n45, p. 16

Figura 7: Anúncio da Unilabor. Fonte: O Estado de S. Paulo. 30 de junho de 1957, p. 12 (recorte).

\section{Moveis 11}

\section{FORMA + FUNÇAO + PRODUÇAO - MOVEIS MODULADOS EM JACARANDÁ DA BAHIA PARA APARTAMENTOS}

Praça da Republica, 119 Fone: 33-1818 Atrás da Escola Normal 
${ }^{5}$ A Unilabor foi registrada na Junta Comercial de São Paulo tendo o início de suas atividades no dia 15/10/1954, sendo como descrição da atividade a fabricação de artefatos de metal para escritório e para usos pessoal e doméstico.
Trata-se de um anúncio de seis linhas, portanto, pequeno, mas que estava no topo da página. O nome adotado já era "UL", e não Unilabor (seu nome de registro é Unilabor, Indústria de Artesanatos de Ferro, Metais e Madeira Ltda. $)^{5}$. Essa grafia foi adotada oficialmente, pois é assim que consta em seu catálogo de vendas e parte dos seus anúncios e o próprio frei João Baptista adotou a grafia UL: "a nossa UL como agora dizemos (pronunciar U-éle)" (SANTOS, 1962, p. 60).

O anúncio mistura fontes serifadas e não-serifadas. A centralidade está na frase "FORMA + FUNÇÃO + PRODUÇÃO". Esse é um ponto relevante para a análise da publicidade da Unilabor. A expressão a forma segue a função já era conhecida na arquitetura e no design, traduzida da frase form follows function, atribuída ao arquiteto Louis Sullivan (1856 - 1924), da Escola de Arquitetura de Chicago (CURTIS, 2008, p. 44-45).

O ideal funcionalista tinha a intenção de difundir para os criadores que as formas (seja de construções, produtos ou até mesmo imagens) deveriam estar relacionadas às funções específicas com os projetos, e, desse modo, a crítica ao ornamento é uma das principais pautas. Esse princípio foi adotado no design na Bauhaus e na Escola de Ulm, na Alemanha, ambas fontes de inspiração e pesquisa de Geraldo de Barros.

Mas e a produção? Essa é uma novidade da leitura do conceito de form follows function. Em um texto publicado antes do anúncio, em março de 1957, na Revista Acrópole, essa frase é aprofundada (figura 8).

Em uma linguagem, estrutura e formato de manifesto, a publicação ocupa duas páginas. O texto, com fonte não-serifada, está disposto apenas em uma parte da primeira página, pois está circundado com os móveis da Unilabor. Não é possível saber quem o redigiu, e há apenas o crédito das fotos a German Lorca (1922). Mas não se trata de um anúncio, nem tampouco de um texto jornalístico. A hipótese de que seja um manifesto é reforçada, uma vez que não há nenhuma demonstração comercial na matéria, como por exemplo, o endereço da fábrica ou até mesmo da loja, já inaugurada naquele período.

O texto presente nessa publicação merece uma análise detida acerca da apropriação que a Unilabor fez sobre o conceito de form follows function e a relação com a produção:

O desenho industrial contemporâneo resolve problemas de forma, função e produção. A máquina substitui a ferramenta. As modernas escolas de arte plástica preparam o desenhista industrial, tornando-o capaz de realizar projetos a base de novos materiais e de baixo custo de produção. Os desenhos aqui apresentados procuram resolver problemas de forma com materiais de alta resistência, porém visualmente leves; problemas de função, pois são anatômicos e foram desenhados levando em consideração o pequeno espaço do apartamento; problemas de produção, uma vez que os materiais empregados são de baixo custo e a mão de obra econômica. (ACRÓPOLE, 1957, p. $184-185$ )

É necessário problematizar esse texto, principalmente a partir das contradições já levantadas do projeto da Unilabor, uma vez que se pretendia uma comunidade de trabalho com o modelo do movimento Economia e Humanismo, mas que também pretendia fazer parte - inclusive para ser sustentável - de um circuito de venda de móveis e estabelecer concorrências com outras fábricas similares. 
Figura 8: Móveis U.L. Fonte: Revista Acrópole. Março de 1957, n²21, págs. 184-185.
Aliás, a questão da produção na publicidade é permeada por tensões. Em sua pesquisa, Anna Cristina Camargo Moraes Figueiredo disserta sobre a questão do trabalho e das figuras de trabalhadores presentes nas peças publicitárias. Ela afirma que a partir das imagens por ela analisadas, o trabalho, quando figurado, não tinha qualquer aproximação com aquele praticado no cotidiano das fábricas, justamente pelo fato da linguagem publicitária não reproduzir discursos hiper-realistas, sobretudo com o tema do trabalho, que envolvia a linha de produção, a exploração etc. (FIGUEIREDO, 1998, p. 54)

Por conta do contexto em que o Brasil incorpora "àqueles anos de 1950 e 1960 o padrão norte-americano de industrialização, tanto no que concerne ao paradigma tecnológico, à estrutura produtiva ou à organização do trabalho taylorista e fordista" , a tendência observada é justamente a figura do consumidor nos anúncios, ou seja, a de se "exaltar cada vez menos o trabalho e a produção" (FIGUEIREDO, 1998, p. 75-76).
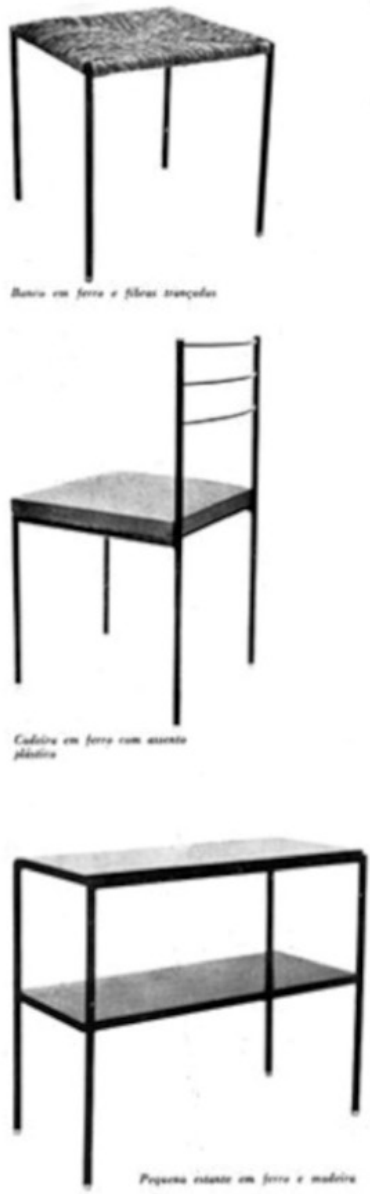

MOVEIS V.L.
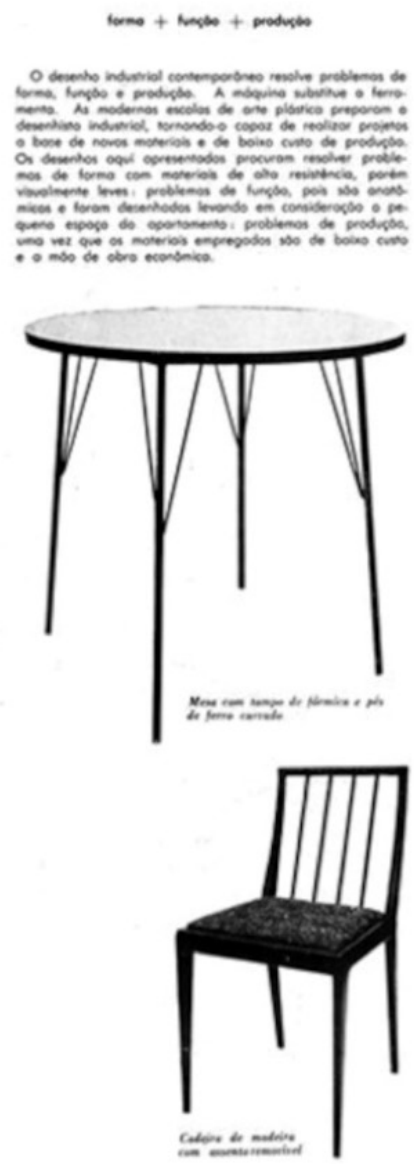
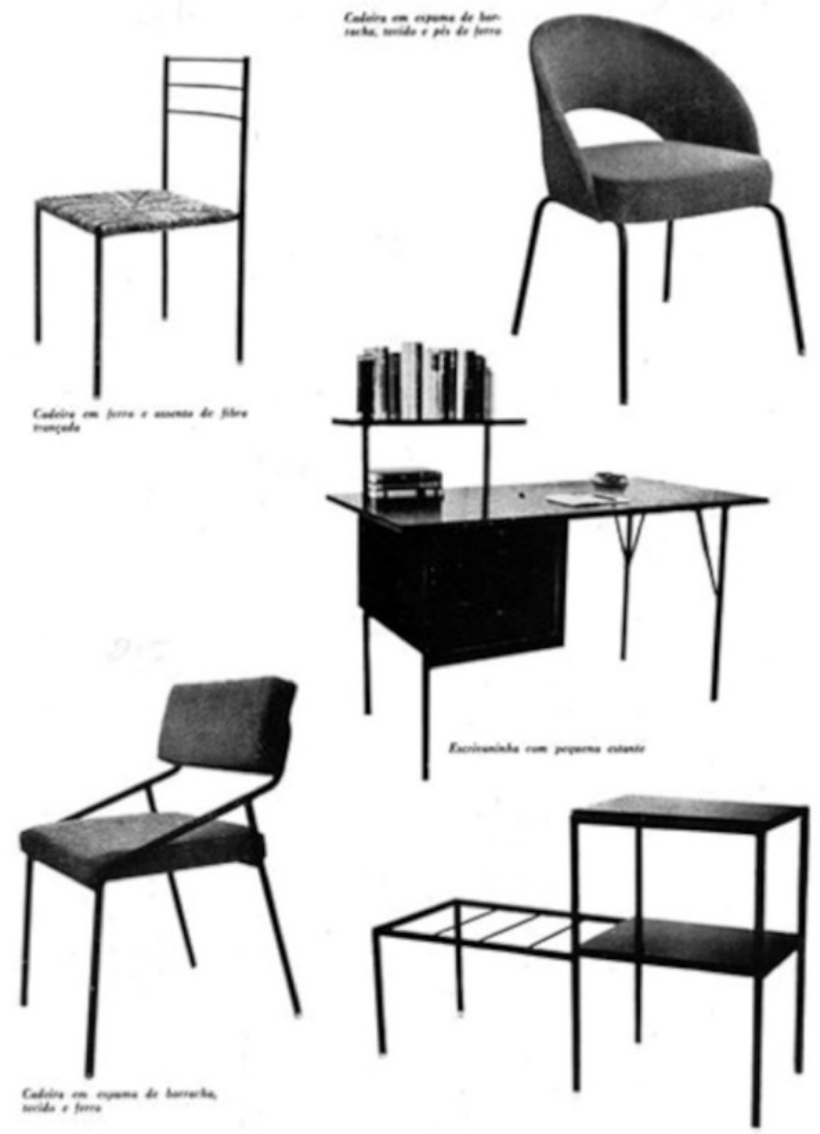
A Unilabor, como se verifica, seguia essa tendência em seus anúncios. Mas por qual motivação? A da reprodução dos recursos publicitários correntes? A falta de profissionalização? Ou por pautar uma publicidade que, mesmo que de uma empresa com ideais diversos, talvez priorizasse outros pontos, como as questões das artes gráficas?

Há um jogo de tensões entre o desenho industrial (e, portanto, o desenhista) e a resolução de problemas. Logo, diferente do discurso que enfatizava a questão comunitária do trabalho, nesse texto a intenção foi exaltar um cargo específico, do desenhista (que, no caso da Unilabor, e naquela data, fazia referência direta a Geraldo de Barros).

Também nos chama a atenção que uma das preocupações era a redução dos custos com a produção, a partir de novos materiais e da "mão de obra econômica", ou seja, barata. Essa qualidade presente na matéria é oposta aos pressupostos do movimento Economia e Humanismo, por dois motivos: não era comum os trabalhadores serem reduzidos ao termo "mão de obra", uma vez que o projeto de humanização do trabalho passava, inclusive, por dar rostos visíveis a essas pessoas, e também a ideia não era baratear a produção por conta de uma "mão de obra econômica", mas adequar os salários para que fossem justos aos ofícios exercidos (sobretudo no caso da Unilabor, em que a especialização era importante).

Por fim, nota-se que o desenho do móvel foi criado levando em conta "o pequeno espaço do apartamento". Ora, a questão da vocação de móveis para apartamentos já estava exposta. O que leva uma empresa a anunciar um produto para um uso específico, e não um uso amplo? Por que enfatizar a questão dos apartamentos? Pode ser uma questão de exaltar um símbolo da modernidade (o apartamento) e o móvel da Unilabor, também moderno, criando uma relação harmoniosa? O elemento da modulação como atributo dos móveis modernos pode ser uma chave de leitura para essas questões.

\section{Anúncios Modelares, Apartamentos Modulados}

Na revista Casa \& Jardim, o primeiro anúncio da UL foi publicado apenas em 1959 (figura 9). Esse anúncio ocupa um quarto de página da revista e foi impresso em preto e branco e possui imagem e texto em fonte não-serifada. Na parte superior figuram algumas possibilidades dos móveis da Unilabor, em sua maioria as estantes. Na parte inferior, o texto dá a dimensão do que está supracitado: a adaptação da produção de mobiliário para as novas configurações de espaço. Os atributos são: modulados, desmontáveis, funcionais e econômicos. Se inferirmos que há uma ordem hierárquica, a modulação ocupa o primeiro lugar.

Ao analisarmos os aspectos gráficos do anúncio, nota-se que sua estrutura é uma reprodução da modulação dos móveis, destacando e reforçando, graficamente, a importância da divulgação da modulação para a fábrica. Esse e os outros atributos não estão ligados propriamente à questão estética nem mesmo de conforto, mas estão relacionados com a questão do móvel presente no espaço.

Porém, nos chama a atenção o texto final: "desenhados para atender às necessidades do pequeno espaço". O texto publicitário coloca para o móvel uma vocação, ou seja, 


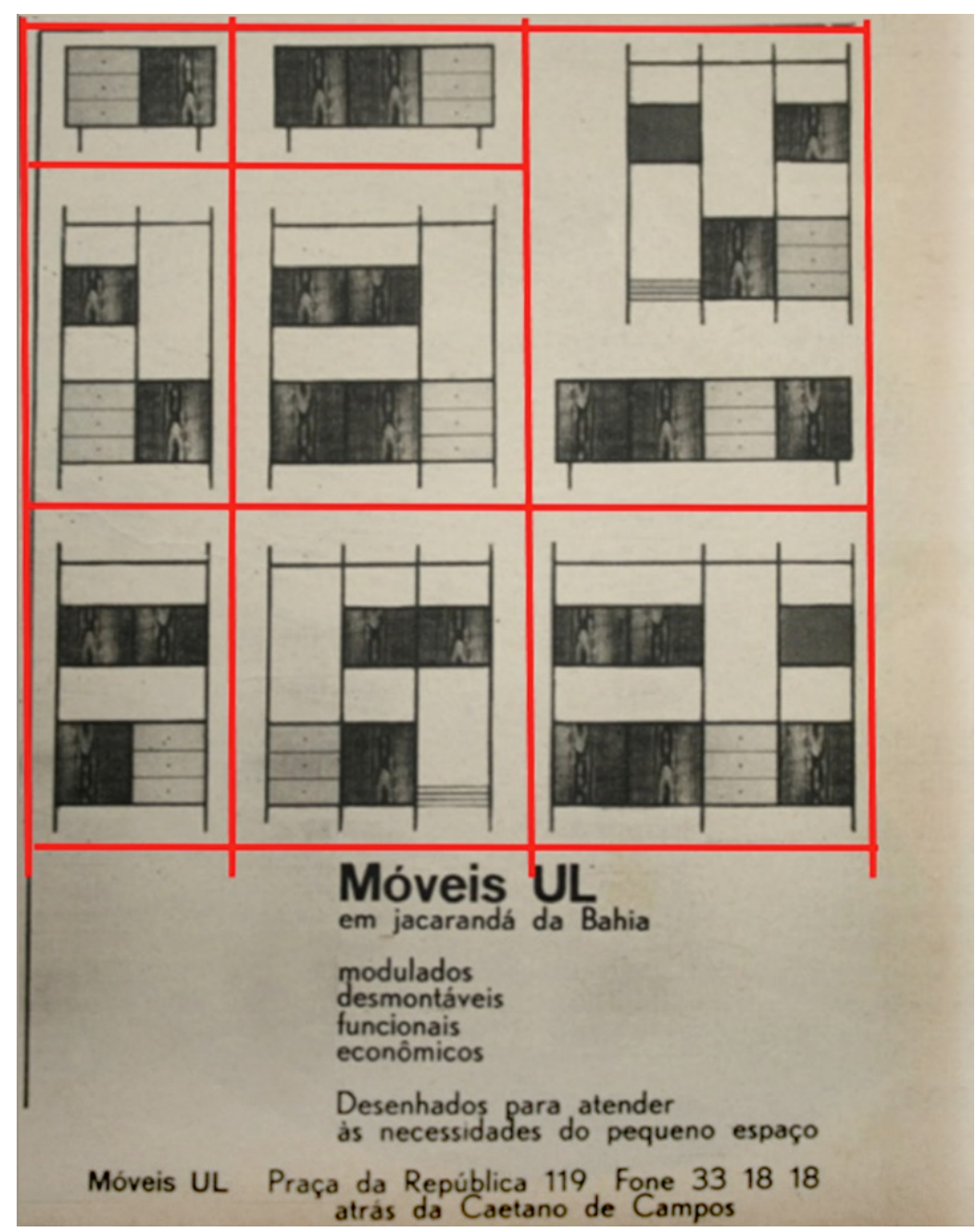

Figura 9: Anúncio Unilabor Sobreposição de linhas para evidenciar a estrutura modular do anúncio.. Fonte: Revista Casa \& Jardim. Agosto de 1959, $\mathrm{n}^{\circ}$ 55, p. 31. que é adequado ao pequeno espaço. Dessa forma, a linguagem publicitária empregada no anúncio coloca um recorte para os clientes da Unilabor: preferencialmente os que moravam no pequeno espaço, e que, portanto, precisariam de novos jeitos de morar e decorar.

Alguns anúncios colocam os móveis da Unilabor em uso no espaço da casa. Uma dessas peças é duplamente interessante, inclusive, por não ser da fábrica, mas da venda de apartamentos na cidade de Santos, litoral do estado de São Paulo, como a primeira imagem referida no parágrafo que segue (figura 10).

Em um anúncio de uma página inteira, em mais da metade há três figuras, com os dizeres "Para a Família Tôda [sic]... Saúde... Férias!". A primeira imagem é a que nos interessa, pois trata dos móveis da Unilabor. 


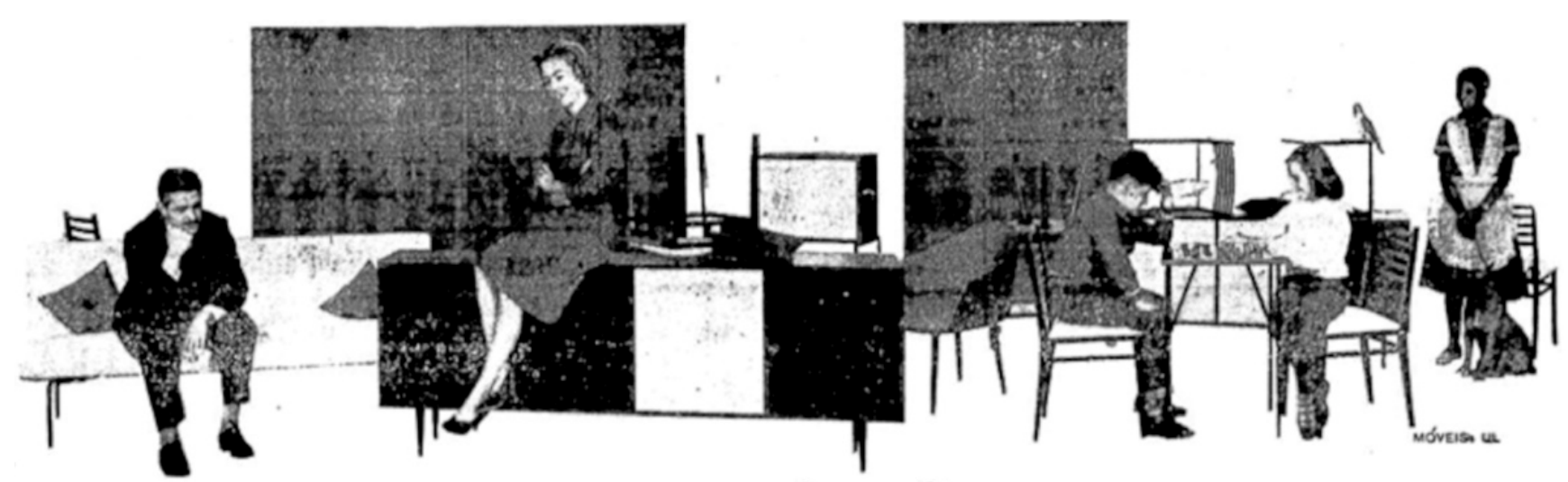

PARA A FAMILIA TÔdA...

Figura 10: Recorte de anúncio Fonte: Folha de S. Paulo, 03 de agosto de 1960, Economia e Finanças, p. 8.
É uma incógnita como foi o processo de escolha para os móveis da Unilabor figurarem no anúncio. Há, no entanto, algumas hipóteses: 1) a fábrica começou a se estabelecer em um circuito de mercado de móveis modernos e de grife; 2 ) frei João Batista poderia ter algum tipo de relação com diretores da imobiliária ou da construtora; 3) a equipe responsável pelo anúncio sabia da existência da Unilabor e tinha admiração pelo mobiliário; e 4) a Unilabor procurava outras empresas para investir na publicidade casada. Todas essas hipóteses são plausíveis, ainda que existam outras. Infelizmente, a Folha de S. Paulo não possui ou disponibiliza para consulta os contratos de publicidade para pesquisa.

Mas, o que nos chama a atenção, todavia, é que os móveis da Unilabor, diferentemente de outros anúncios, estão dispostos em uso e ligados a uma questão específica: a família, ratificando a leitura de Sabrina Studart Fontenele Costa, de que inovação e reforço da representação da família tradicional, são características dos lares modernos, sobretudo quando há o papel feminino, "ora como símbolos de inovação dos modos de vida, ora como possibilidade de representação da família tradicional" (COSTA, 2017, p.2). Diferente do anúncio anterior, em que atributos próprios da casa moderna são exaltados, aqui não há atributos ligados ao mobiliário, e, portanto, esse faz um papel secundário, servindo de suporte para a instituição familiar.

O anúncio, inclusive, reproduz uma lógica específica e de família que representa os segmentos médios: pai, mãe, dois filhos empregada. Analisando mais a fundo, podemos observar qual é o tipo de lógica familiar presente. Se fizermos uma leitura ocidental, ou seja, da esquerda para direita, o primeiro personagem é o pai/marido: homem, branco, sentado, em uma posição que se aproxima da imagem do pensador, o que é confirmada em sua expressão séria e com punho cerrado.

A segunda pessoa na escala de importância segundo essa leitura é a mãe/esposa: sentada em um móvel, rindo, sua imagem se aproxima das modelos que demonstram produtos. Sua posição corporal é fluída, em relação à do marido, e a coloca como um enfeite na casa, uma peça de decoração. Seus pés não tocam o chão, diferente de todos na cena, fazendo com que sua posição não fosse de total conforto. 
Em outra leitura possível, ela não toca os pés no chão porque estava em um ambiente que acabara de ser limpo, por isso a expressão de insatisfação e tédio do marido, que não poderia se movimentar. Essa análise é possível também ao observarmos o desenho dos móveis da Unilabor: suas cadeiras são ausentes de braços, o que facilita a organização do espaço para a limpeza, podendo ser empilhadas em cima de outros móveis para deixar o chão livre.

Os filhos reproduzem a mesma ordem e posições aproximadas dos progenitores: a figura masculina vem em primeiro lugar, colocando seu corpo em postura de concentração, com as pernas a 90 graus. Já a figura feminina representa uma criança relaxada, com uma postura fluída, não ocupando totalmente o espaço da cadeira, figurando, dessa forma, semelhante à mãe. Inclusive, pai e filho e mãe e filha, ocupam, na cena, direção e sentido iguais, possibilitando a leitura de um recorte de gênero cristalizado e a ser seguido vida afora.

Por fim, na ordem de importância, segundo essa leitura, está a figura representando a empregada doméstica. É negra, e a única pessoa que não está sentada, e, portanto, não está em uma posição confortável. Inclusive, a possibilidade de conforto para ela é negada, visto que a cadeira atrás dela está de costas. Ela também está levemente em segundo plano e junto com os animais. Se levarmos em conta a legenda da imagem, ela faz parte da família, mas, como visto, não carrega os sinais de distinção social, ocupando a setorização mais subalterna na montagem do "lar" burguês (BOURDIEU, 2007, p. 14).

Esse anúncio é importante por conter diversas possibilidades de análise, como de gênero e raça, e isso ser uma novidade (e exclusividade) na série documental das peças publicitárias da Unilabor, pois anuncia um ideal de casa e de morar que cria um conjunto visual de decoração, mas também de sociabilização.

Além disso, evidencia também um problema para pensar a atuação da Unilabor: por um dos seus idealizadores ser um frade dominicano, é possível que a estrutura familiar tivesse um apelo religioso nesse sentido, ainda que, como supracitado, seja, esse, o único anúncio com essa intenção. De fato, o ideal evangelizador, mesmo que por atributos tangentes (como a família nuclear cristã católica), não teve lugar nos anúncios da Unilabor. Esse papel foi, novamente, realizado dentro dos muros da fábrica, sendo que frei João Baptista cumpria essa função de evangelização com os operários, as famílias destes e em todo o bairro no entorno da fábrica.

A leitura e análise desse anúncio divergem do panorama que a pesquisadora Joana Mello sintetiza acerca desse processo de apropriação dos princípios modernos para a arquitetura e sua aceitação nos lares, a partir de diversos agentes, sobretudo as mulheres, leitoras e consumidoras de revistas de curiosidades, arquitetura, designer e decoração, além das especializadas na temática doméstica, que propagavam e difundiam discursos e imagens de uma vida moderna. Joana Mello aponta que:

são claras também as aproximações com as máquinas e os seus ideais de funcionalidade, eficiência e modernidade, ideais vinculados à racionalidade industrial seriada de matriz taylorista. Sem dúvida, é nesse contexto que o ideal de eficiência passa a reger também do ponto de vista da clientela o funcionamento da casa. Um contexto 
de metropolização intensa em que as famílias, especialmente as de classe média, tinham menos empregados; as mulheres começam a sair de casa e se alteram hábitos de consumo, formas de morar e de estar na cidade. [...] Essas mudanças são acompanhadas pela afirmação de um modo de vida mais despojado, menos hierarquizado, próximos do ideal do american way of life, manifesto não apenas na casa, mas também no mobiliário e até mesmo no vestuário. (MELLO, 2014, p. 39)

Portanto, esse morar anunciado, não exatamente pela Unilabor mas com um de seus móveis como suporte, segundo a pesquisadora, não se alinhava exatamente com categorias modernas de independência, desierarquização etc.

Outras temáticas surgem nos anúncios: as possibilidades de análise para o morar em relação aos novos materiais. Em uma peça publicitária da Formica (figura 11), de página inteira, alguns móveis da Unilabor aparecem com a textura de jacarandá da baía de Formica ao fundo.

Além da imagem, o anúncio tem um texto que merece uma análise mais profunda: "Ela abriu novas possibilidades... Olhe em redor! Veja como Formica influiu no bem estar da vida moderna! Como ela abriu novas possibilidades na arquitetura, na decoração, na fabricação de móveis. O que hoje não se faz de Formica?" (CASA \& JARDIM, 1961, p. 19).

Esse texto coloca a premissa de que o uso de materiais é explorado na publicidade para os produtos dos lares modernos. Nesse caso, a Formica, aplicada ao mobiliário, é um atributo de valorização, ainda que não especifique quais seriam as qualidades (talvez durabilidade, limpeza, acabamento).

É importante notar que a publicidade da Formica sustenta um discurso, ilustrado com móveis da Unilabor, que a casa moderna, ou, na linguagem do próprio anúncio, o bem-estar, está atrelado ao uso de materiais que, de certa forma, cobrem a madeira e aplicam um revestimento industrial, novo, despojado (mesmo que imite a madeira).

Ressaltamos, inclusive, que um dos materiais da Unilabor, no caso um cartão de visita, também imitava um laminado de Formica, conferindo também a suas peças internas os atributos relacionados a inovação da Formica acima descritos.

\section{Considerações Finais}

Caminhando para uma conclusão, percebemos que é importante salientar que o mobiliário, muitas vezes, é escolhido para os lares a partir de diversos critérios, dentre eles, o da racionalização do espaço da casa; a busca de um alinhamento aos móveis quanto ao seu valor artístico - e do design; e a um processo de aprendizado e aplicação do bom gosto, e que, portanto, a publicidade faz parte dessa rede complexa de formação de uma imagem da casa a partir do móvel para anunciar um modo de morar a partir de padrões ditos modernos.

Esses critérios, também analisados pela pesquisadora Silvana Rubino, nos trazem a dimensão da domesticidade e da função dos artigos de aconselhamento sobre a 


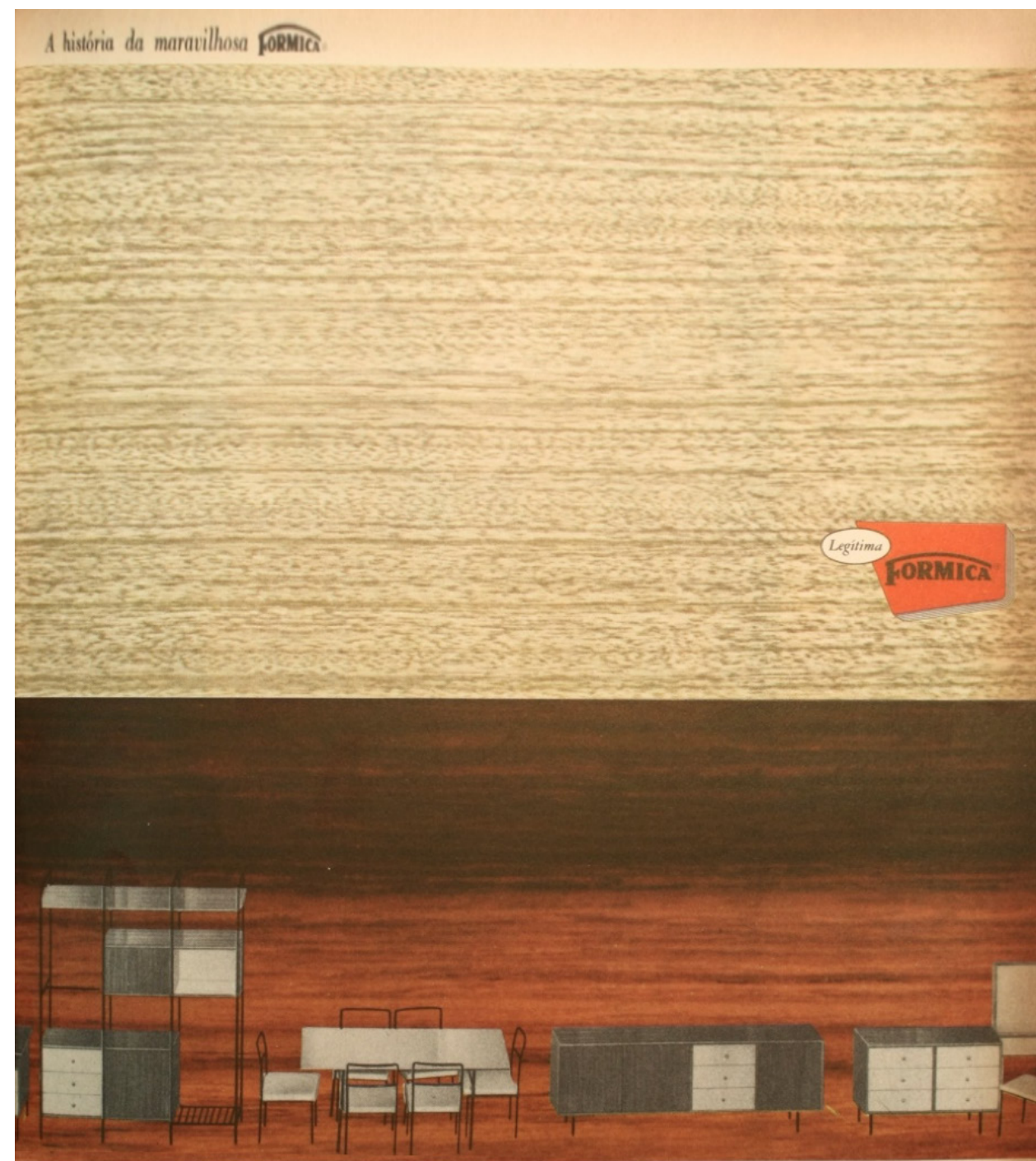

Ela abriu novan ponnibilidaden...

Olhe em redor! Veja como FoRMIC influiu no bem estar da vida moderna! Como ela abriu novas possibilidades na arquitetura, na decoração, na fabricaçâo de móveis. O que hoje não se faz de formå ? Móveis são feitos de formicr. Cádeiras são feitas de formiar. Mesas são feitas de pormicr. Mesas são feitas de Formica. Mais mesas são feitas de Formica! Armários sâo feitos de Formicr. Lambrís são feitos de Formica. Balcōes são feitos de Formicr. Painéis e divisões são feitos de FoRMIcr. Portas são feitas de Formar. Ete, etc, etc...também são feitos de Formicr.

Figura 11: Peça publicitária da Fórmica. Fonte: Casa \& Jardim, novembro de 1961, n $^{\circ} 82$, p. 19. 
casa e o morar. Nesse sentido, entendemos que a publicidade e os catálogos cumprem um papel fundamental (RUBINO, 2016, p. 12).

Além das características apontadas acerca do mobiliário, a Unilabor tem o projeto de desalienação do trabalho levado a cabo por um frade envolvido nas questões trabalhistas e políticas. Essa questão moral do trabalhador ganha, na Unilabor, outras nuances, pois passa da casa (uma vez que os móveis atingiam segmentos médios da sociedade) para a fábrica.

No plano das artes, podemos analisar justamente as imbricações geradas a partir da questão da arte industrial, sobretudo no que diz respeito ao design e a publicidade. Nesse sentido, Eric Hobsbawm em um ensaio acerca da arte-pop, diz que:

A revolução industrial que ocorreu nas produções da mente, como a das produções materiais, tem duas causas: o progresso técnico, que substitui as habilidades manuais, e a demanda de massa, que as torna inadequadas. Seu aspecto crucial não é simplesmente a capacidade de reproduzir criações individuais em grande quantidade [...] mas a capacidade de substituir a criação. [...] É a dissolução do produtor individual numa cooperativa. (HOBSBAWM, 2013, p. 300-301)

Logo, vimos que a publicidade da Unilabor seguia a orientação de diversos contextos: uma fábrica com um ideal diferente de produção e com uma ideologia de terceira via, mas que precisava se manter comercialmente frente a outras fábricas e lojas, e, portanto lançar mão de uma de suas principais ferramentas, a propaganda.

Também havia o seu recorte religioso, uma vez que, por mais que não fosse uma obra religiosa por si, havia ali símbolos cristãos católicos presentes: uma capela, trabalhos pastorais e a presença de um frade, enquanto, por outro lado, se pretendia moderna; o padrão da publicidade brasileira alinhado a uma escola de propaganda americana, em um contexto de Guerra Fria, mas que tinha artistas próximos estudando outras vertentes; e, por fim, a valorização do trabalho e do trabalhador, que eram vistos como um trunfo da fábrica, de caráter extraordinário para o período, mas que tanto no processo de produção do anúncio, quanto no próprio anúncio, não perpassava a classe laboral.

Podemos também, dentro desse escopo, considerar que a Unilabor não pretendia ser uma empresa de sucesso, ou seja, uma líder de vendas dentro do segmento como as congêneres do período, mas um experimento de uma outra possibilidade de empresa e de relações, mas, que ainda assim, necessitava se comportar com uma comercialização minimamente competitiva (haja vista sua expansão para ao menos quatro lojas).

Dessa forma, concluímos que, por essa intersecção de situações, a publicidade da Unilabor continha contradições a partir de um projeto de empresa. Aliado a isso pudemos observar, a partir da documentação, certo descolamento com o padrão de publicidade vigente que foi analisado, pois não havia uma organização aparente da publicidade, revelado por sua periodicidade esparsa, falta de padrão em textos, tipos, colocações da marca. Esse fato aponta que a publicidade não era uma prioridade, mesmo que houve um setor de comunicação e também artistas com experiência em publicidade envolvidos no projeto, denotando uma disputa de pensamentos acerca do que e de como deveria ser publicado. 


\section{Referências bibliográficas}

ANGELO, Michelly Ramos de. Les Développeurs: Louis-Joseph Lebret e a SAGMACS na formação de um grupo de ação para o planejamento urbano no Brasil. Tese (Doutorado em Teoria e História da Arquitetura e do Urbanismo) - Escola de Engenharia de São Carlos, Universidade de São Paulo, São Carlos, 2010.

BALLENT, Anahi. A "casa jovem": imagens da modernização do lar nos anos 1960 e 1970 na revista Claudia da Argentina. In: Domesticidade, gênero e cultura material. São Paulo: EDUSP/CPC, 2017.

BARROS, Fabiana de (org.). Geraldo de Barros: isso. São Paulo: SESC, 2013.

BOSI, Alfredo. Economia e humanismo. Estudos avançados, São Paulo, v. 26, n. 75, 2012.

BOURDIEU, Pierre. A Economia das trocas simbólicas. São Paulo: Perspectiva, 2007.

CLARO, Mauro. Unilabor: desenho industrial, arte moderna e autogestão operária. São Paulo: Senac, 2004.

COSTA, Sabrina Studart Fontenele. Modos de morar na metrópole: a representação das mulheres e da domesticidade nos apartamentos duplex modernos. Anais eletrônicos do Seminário Internacional Fazendo Gênero, Florianópolis, 2017.

CURTIS, William J. R. Arquitetura Moderna desde 1900. Porto Alegre: Bookman, 2008.

FIGUEIREDO, Anna Cristina Camargo Moraes. "Liberdade é uma calça velha azul e desbotada": publicidade, cultura de consumo e comportamento político no Brasil (1954-1964). São Paulo: Hucitec, 1998.

FORTY, Adrian. Objetos de desejo - Design e sociedade desde 1750. São Paulo: Cosac Naify. 2013.

GINZBURG, Carlo. O Queijo e os vermes: o cotidiano e as ideias de um moleiro perseguido pela Inquisição. São Paulo: Companhia das Letras, 2011.

HOBSBAWM, Eric J. Tempos Fraturados: Cultura e Sociedade no século XX. São Paulo: Companhia das Letras, 2013.

MELLO, Joana. O avesso da arquitetura moderna: domesticidade e formas de morar na habitação privada brasileira 1940-1960. Contraste, São Paulo, n. 3, 2014.

MELO, Chico Homem de. O design brasileiro: anos 60. São Paulo: Cosac Naify, 2014.

PONTUAL, Virgínia. Louis-Joseph Lebret na América Latina: um exitoso laboratório de experiências em planejamento humanista. Rio de Janeiro: Letra Capital, 2016.

RUBINO, Silvana. A casa moderna: modos de usar. IV ENANPARQ, Porto Alegre, 2016.

SABO, André Lacroce. Ruben Martins: Trajetória e Análise da Marca Rede de Hotéis Tropical. Dissertação (Mestrado em Design e Arquitetura) - Faculdade de Arquitetura e Urbanismo, Universidade de São Paulo, São Paulo, 2011.

SANTOS, Frei João Baptista Pereira dos. Unilabor: Uma revolução na estrutura da empresa. São Paulo: Livraria Duas Cidades, 1962. Os chifres do diabo - capitalismo e comunismo. São Paulo: SAL, 1964.

WOLLNER, Alexandre. Design visual: 50 anos. São Paulo: Cosac Naify, 2003. 